\title{
PEMBELAJARAN BAHASA ARAB \\ DI PROVINSI LAMPUNG TAHUN 2016
}

\author{
Akla \\ Institut Agama Islam Negeri Metro \\ Email:akla.hasan@gmail.com
}

\begin{abstract}
This research aims to reveal the data of Arabic language learning in Lampung. This research is focused on teachers professionality, Arabic learning process, and students' Arabic language skills that consist of istima', kalam, qira'ah, and kitabah. This research refers to a survey study by collecting information from sample through questionnaire. The objectives of this research not only examine the map of teachers professionality, Arabic learning process, and students' Arabic language skills but also find out the interaction between learning process and students' Arabic skills. The samples of this research were 49 Arabic teachers and 382 students of Islamic Senior High School around Lampung. From the results of analysis data, it can be concluded that teachers professionality belongs to medium level, Arabic learning process belongs to medium level, students' Arabic language skills belong to low level. The results of associative analysis showed that there is a significant influence between learning process and students' Arabic language skills; therefore, it can be regarded that un-maximal learning process and environment have an impact towards the students low-level Arabic language skills.
\end{abstract}

Keywords: learning, Arabic Language

\section{A. Pendahuluan}

Undang-Undang Negara Republik Indonesia tahun 2003 nomor 20 tentang sistem pendidikan nasional memberikan amanat kepada penyelenggara pendidikan untuk menghasilkan lulusan yang memiliki daya saing tinggi, memiliki kekuatan spiritual keagamaan, cerdas secara emosi dan intlektual, berakhlak mulia dan terampil. Pencapaian amanat ini, terutama untuk menghasilkan lulusan berdaya saing tinggi baik secara regional, nasional dan internasional, tentu penguasaan bahasa asing perlu menjadi prioritas. Madrasah Aliyah (MA) adalah salah satu penyelenggara pendidikan memiliki tanggung jawab besar melahirkan lulusan bermutu dengan penguasaan bahasa asing semisal bahasa Arab. Pembelajaran bahasa Arab di Madrasah Aliyah memiliki peran penting dalam proses pembangunan bangsa dan negara, terutama dalam rangka mempersiapkan generasi tangguh yang mampu bersaing di dunia internasional. Perubahan zaman akibat dari perkembangan ilmu pengetahuan dan teknologi harus disejajarkan dengan lulusan yang berkualitas. Oleh karena itu, proses 
pembelajaran bahasa Arab yang berhasil dan berkualitas merupakan salah satu syarat mutlak untuk mewujudkan lulusan yang berdaya saing.

Untuk menghasilkan generasi yang unggul, lembaga MA harus menjalankan proses pembelajaran secara maksimal yang di motori oleh guru yang profesional dibidangnya yang mampu menjalankan proses pembelajaran secara optimal. Guru profesioanl adalah guru yang terus berupaya menciptakan proses belajar mengajar interaktif dalam rangka terciptanya proses belajar mengajar yang efektif dan efisien. ${ }^{1}$ Dalam proses pembelajaran guru juga melakukan aktivitas psikis atau mental yang berlangsung dalam interaksi aktif pada lingkungan belajar, guna menghasilkan perubahan baik pengetahuan, pemahaman, keterampilan maupun nilai sikap. ${ }^{2}$ Oleh karena itu proses pembelajaran yang baik hendaknya terdapat interaksi dua arah yang tidak dapat dipisahkan. Dalam proses interaksi ini guru dapat melakukan refleksi guna memperbaiki proses yang akan dilakukan guna membantu peserta didik menjadi lebih peka dengan informasi yang diperoleh dan memudahkan guru dalam menciptakan pembelajaran yang diinginkan. ${ }^{3}$ Refleksi ini dapat dilakukan dengan melakukan evaluasi dari apa yang sudah dijalani dengan menuliskannya pada jurnal guru dan peserta didik yang dirancang untuk mendokumentasikan apapun yang diperoleh dari proses pembelajaran. Dengan menuliskan materi, sikap, dan situasi disetiap pembelajaran, maka baik peserta didik maupun guru akan melakukan refleksi dan belajar dari pembelajaran yang telah dilalui. ${ }^{4}$ Oleh karenanya proses pembelajaran yang baik harus terjadi timbal balik antara guru dan peserta didik yang berlangsung dalam situasi edukatif untuk mencapai tujuan belajar.

Berlangsungnya proses pembelajaran bahasa Arab selalu terkait dengan komponen-komponen yang ada di dalamnya. Komponen-komponen itu berupa peserta didik, guru, tujuan pembelajaran, materi, metode, media dan evalusi. 5 Terdapat beberapa komponen dalam proses pembelajaran bahasa Arab yang memberikan pengaruh besar terhadap ketercapaian tujuan pembelajaran. Komponen

${ }^{1}$ Bafadal Ibrahim, Dasar-Dasar Manajemen Dan Supervisi Taman Kanak-Kanak (Jakarta: PT Bumi Aksara, 2005), h. 11.

2 Winkel, Psikologi Pengajaran (Jakarta: Grasindo, 1996), h. 200.

3 J. John Loghran, Developing Reflective Practice (London: Falmer Press, 2005), h. 4.

4 Ibid., h. 7.

5 Mudjiono Dimyati, Proses Belajar Mengajar (Jakarta: Bumi Aksara, 2006), h. 23. 
tersebut terdiri dari komponen guru, komponen peserta didik , komponen sarana dan prasarana dan komponen lingkungan belajar". ${ }^{6}$ Dalam proses pembelajaran bahasa Arab, guru merupakan salah satu komponen penentu keberhasilan berbahasa peserta didik. Guru merupakan ujung tombak yang berhubungan langsung dengan peserta didik. Bagaimanapun bagus dan idealnya kurikulum pengajaran bahasa Arab, lengkapnya sarana dan prasarana pendidikan, tanpa diimbangi dengan kemampuan guru dalam mengimplementasikannya, maka akan sulit mengantarkan peserta didik pada keterampilan berbahasa dengan baik. Oleh sebab itu, untuk dapat mengantarkan peserta didik pada kemampuan berbahasa Arab diperlukan guru profesional.

Guru profesional merupakan tuntutan mutlak dalam pembelajaran bahasa Arab dan menjadi faktor penentu keberhasilan penguasaan berbahasa Arab peserta didik. Ia tidak hanya mengajar, tapi lebih dari itu ia juga sebagai pendidik, pembimbing, pelatih dan pemimpin yang dapat menciptakan iklim belajar bahasa Arab yang menarik dalam kelas. Guru yang profesional adalah individu yang bekerja sesuai dengan standar moral dan etika yang ditentukan oleh pekerjaan tersebut.7 Guru bahasa Arab yang profesional adalah guru yang menjalankan tugasnya sesuai dengan pengalaman dan pengetahuannya dengan menempatkan peserta didik sebagai pembelajar serta mampu mengembangkan dan melaksanakan kurikulum dalam proses pembelajaran. ${ }^{8}$ Oleh karena itu guru bahasa yang profesional memiliki kompetensi yang dipersyaratkan untuk melakukan tugas pendidikan dan pengajaran yang memiliki kemampuan dan keahlian khusus dalam bidang keguruan sehingga ia mampu melakukan tugas dan fungsinya sebagai guru dengan kemampuan maksimal. Ia juga terdidik dan terlatih dengan baik, serta memiliki pengalaman yang kaya dibidangnya. ${ }^{9}$

Guru bahasa Arab yang profesional mampu melaksanakan tugas profesinya secara efektif dan efisien, berpikir proaktif, merumuskan tujuan pengajaran bahasa secara jelas, menyusun skala prioritas dimulai keterampilan listening (istima') dilanjutkan (speaking) kalam, reading (qira'ah) dan writing (kitabah), Ia juga berpikir

\footnotetext{
6 Ibid., h. 53-54.

7 J.J Phillips, Handbook of Training Evaluation and Measurement Methods (Houson: Publishing Company, 1991), h. 43.

8 Paul Cooper and Paul McIntyre, Effective Teaching and Learning (Philadelphia: Open University Press, 1996), h. 6.

${ }_{9}$ Kunandar, Guru Profesional Implementasi Kurikulum Tingkat Satuan Pendidikan (KTSP) Dan Persiapan Menghadapi Sertifikasi Guru (Jakarta: PT Raja Grafindo Persada, 2007), h. 45.
} 
maju mengikuti perkembangan pengajaran bahasa sasaran, mampu bekerja dalam tim, memiliki empati, dan senantiasa mengembangkan diri. ${ }^{10}$ Guru profesional juga ditandai oleh prilaku berpikir aktif dalam mencari cara yang lebih baik dalam mengajar dan selalu berusaha menggunakan pendekatan yang berbeda dalam proses pengajarannya. ${ }^{11}$ Maka guru dikatakan profesional jika ia memiliki kompetensi: (1) kompetensi pedagogik (2) kompetensi kepribadian (3) kompetensi profesional dan (4) kompetensi sosial. Pada aspek kompetensi pedagogik dalam Standar Nasional Pendidikan (SNP) Pasal 28 ayat (3) butir a dikemukakan bahwa kompetensi pedagogik adalah kemampuan mengelola pembelajaran peserta didik yang meliputi pemahaman terhadap peserta didik, perancangan dan pelaksanaan pembelajaran, evaluasi hasil belajar dan pengembangan peserta didik untuk mengaktualisasikan berbagai potensi yang dimilikinya. 12

Kompetensi pertama yang harus dimiliki guru bahasa Arab adalah kompetensi pedagogik. Kompetensi ini meliputi kemampuan guru dalam memahami karakteristik dan level kemampuan berbahasa peserta didik, kemampuan guru dalam merencanakan dan melaksanakan proses pembelajaran bahasa Arab yang efektif dan menyenangkan serta kemampuan guru dalam menyusun evaluasi belajar dengan mengacu pada konsep evaluasi pembelajaran bahasa Arab.

Kompetensi kedua adalah kompetensi kepribadian. Dalam Standar Nasional Pendidikan pada Pasal 28 ayat (3) butir b, dikemukakan bahwa yang dimaksud dengan kompetensi kepribadian adalah kemampuan kepribadian yang mantap, stabil, dewasa, arif dan berwibawa, menjadi teladan bagi peserta didik dan berakhlak mulia. ${ }^{13}$ Guru bahasa Arab harus memiliki kompetensi kepribadian yang baik agar dapat membimbing peserta didik dalam belajar dan dapat menjadi contoh bagi keseharian peserta didik.

Kompetensi ketiga adalah kompetensi profesional. Dalam Standar Nasional Pendidikan, penjelasan Pasal 28 ayat (3) butir c dikemukakan bahwa yang dimaksud kompetensi profesional adalah kemampuan penguasaan materi pembelajaran secara

10 S. R. Covey, The 7 Habits of Highly Effective People (Jakarta: Binarupa Aksara, 1997).

11 K.T. Henson and B.E. Eller, Educational Psychology for Effective Teaching (Belmont: Wadsworth Publishing Company, 1999).

12 E. Mulyasa, Standar Kompetensi Dan Sertifikasi Guru (Bandung: Rosda Karya, 2008), h. 115.

13 Ibid., h. 117. 
luas dan mendalam yang memungkinkan membimbing peserta didik memenuhi standar kompetensi yang ditetapkan dalam Standar Nasional Pendidikan. ${ }^{14}$ Mengacu pada kompetensi profesional ini, maka semestinya guru bahasa Arab menguasai empat keterampilan bahasa seimbang mulai dari maharah istima', maharah kalam, maharah qira'ah dan maharah kitabah. Disamping menguasai keempat maharah lughawiyah tersebut, guru harus juga mampu mengajarkannya dengan menggunakan strategi dan metode yang variatif dan mampu melaksanakan evaluasi untuk mengukur perolehan belajar peserta didik.

Kompetensi keempat yang harus di miliki oleh guru profesional adalah Kompetensi Sosial. Berdasarkan Standar Nasional Pendidikan, penjelasan Pasal 28 ayat (3) butir d, dikemukakan bahwa yang dimaksud dengan kompetensi sosial adalah kemampuan guru sebagai bagian dari masyarakat untuk berkomunikasi dan bergaul secara efektif dengan peserta didik, sesama pendidik, tenaga kependidikan, orang tua atau wali peserta didik dan masyarakat sekitar. ${ }^{15}$ Standar kompetensi yang keempat ini mengharuskan guru bahasa Arab untuk dapat berinteraksi dan berkomunikasi secara efektif baik sesama guru terkait dengan proses pembelajaran maupun dengan masyarakat sekitar.

Guru yang profesional adalah guru yang memiliki kemampuan yang komprehensif dalam bidang pengajaran terutama dalam penguasaan knowledge-base of teaching-nya. Maka untuk mengukur ini diperlukan standar dan kriteria yang dapat dijadikan parameter kualitas kinerja guru profesional. Suharsimi (dalam Majid) menjelaskan standar yang dimaksud adalah suatu kriteria yang telah dikembangkan dan ditetapkan berdasarkan atas sumber, prosedur dan mamajemen yang efektif. Sedang kriteria adalah sesuatu yang menggambarkan ukuran keadaan yang dikehendaki. ${ }^{16}$ Penetapan standar dalam pengembangan profesi guru adalah sebuah keniscayaan karena ia merupakan gambaran ukuran dari baik buruknya profesi itu. Standar suatu profesi membangun public trust terhadap eksistensi profesi tersebut bagi kepentingan masyarakat luas dan sekaligus pula mengembangkan public

\footnotetext{
14 Ibid., h. 135.

15 Ibid., h. 173.

16 Abdul Majid, Perencanaan Pembelajaran: Mengembangkan Standar Kompetensi Guru (Bandung: Remaja Rosdakarya, 2011), h. 5.
} 
acceptance terhadap segala aspek yang berkaitan dengan kegiatan operasional suatu profesi. ${ }^{17}$

Disamping kompetensi-kompetensi diatas, guru sejatinya juga mampu dalam profesinya dengan menempatkan peserta didik sebagai pembelajar, melakukan penelusuran karakteristik peserta didik terkait identitas, budaya, gaya belajar, kemampuan berbahasa, kondisi keluarga, intelijensi, kesiapan belajar, bakat, dan karakteristik personal lainnya. Kemudian menggunakan informas-informasi ini sebagai need analysis dalam menyiapkan pembelajaran yang kemudian diselaraskan ke dalam strategi mengajar, serta mampu memahami dan melayani peserta didik dalam belajar. ${ }^{18}$ Jika peran guru ini dapat dilakukan dengan baik, maka guru akan dapat menciptakan keteraturan dan dapat memfasilitasi proses belajar peserta didik secara optimal.

Sejalan dengan lajunya teknologi informasi, maka peran dan tanggung jawab gurupun akan semakin kompleks. Guru dituntut dapat melakukan berbagai peningkatan dan penyesuaian kemampuan profesionalnya. Guru harus lebih dinamis dan kreatif dalam mengembangkan proses pembelajaran di kelas. Guru tidak lagi menjadi satu-satunya orang yang paling pintar dihadapan peserta didiknya. Maka guru yang tidak memahami mekanisme pembelajaran yang baik, ia akan mengalami kesulitan dalam menjalankan tugasnya dan tidak akan melahirkan outcome yang kuat dan bermutu. ${ }^{19}$ Jika ini terjadi, guru akan kehilangan kepercayaan baik dari peserta didik, orang tua maupun masyarakat. Untuk mengantisipasi hal ini guru harus melakukan antisipasi dan proaktif dalam melakukan pembaruan ilmu dan pengetahuan yang dimilikinya secara terus menerus. Maka jika ini dilakukan maka akan lahir guru yang profesional yang mampu mengantarkan peserta didik pada tujuan yang ditetapkan.

Namun fenomena rendahnya kualitas dan daya saing lulusan MA di level regional dan nasional pada aspek kemampuan berbahasa Arab, menunjukkan bahwa pendidikan MA belum mampu menghasilkan sumber daya manusia yang berkualitas dan berdaya saing tinggi. Fenomena ini bisa jadi adalah dampak dari rendahnya

17 Ibid.

18 William Powell and Ochan Kusuma, How to Teach Now (Virginia: ASDC, 2011), h. 8.

19 Ibid., h. 9. 
daya saing pendidikan negeri ini. Rendahnya kualitas pendidikan bangsa ditunjukkan pada hasil survey kualitas pendidikan yang dilakukan oleh OECD (Organisation for Economic Co-operation and Development) pada tahun 2015, Indonesia menduduki ranking ke 69 dari 76 negara dunia, jauh berada di bawah peringkat negara tetangga Singapura yang berada di peringkat satu dan Vietnam di peringkat dua belas. Sementara data Indeks Pembangunan Manusia (IPM) pada tahun 2015 yang dikeluarkan UNDP (United Nations Development Programme) PBB, menyatakan Indonesia menempati peringkat ke 110 dari 187 negara, dengan nilai indeks 0,684.Indeks Pembangunan Manusia ini merupakan komposisi dari peringkat capaian pendidikan, kesehatan, dan penghasilan perkepala pertahun.

Kualitas pendidikan Indonesia yang jauh dari ideal ini tentu merupakan cerminan dari kualitas lembaga-lembaga pendidikan negeri ini sehingga luaran pendidikan kurang berdaya saing. Kurang optimalnya kapasitas lembaga-lembaga pendidikan dalam mentranformasikan peserta didik untuk memperoleh nilai lebih terutama dalam penguasaan bahasa Arab. Dan pemeran utama dalam proses transformasi nilai lebih kepada peserta didik adalah guru. Data OECD dan UNDP diatas bisa menjadi baro meter kualitas pembelajaran yang selama ini dilakukan oleh guru belum maksimal. Tidak maksimalnya guru dalam proses pembelajaran tidak bisa diabaikan karena berdampak signifikan pada hasil luaran. Fenomena ini tentu menjadi kegelisahan tersendiri, karena ternyata akar dari ketidakmampuan lulusan terutama dalam penguasaan berbahasa asing harus ditelusuri secara teliti sebagai pijakan dalam memberikan solusi dan alternatif pemecahan. Untuk itu maka peneliti merasa penting untuk melakukan penelitian tentang pembelajaran bahasa Arab di Madrasah Aliyah Negeri Provinsi Lampung.

Sub fokus penelitian ini adalah profesionalisme guru, proses pembelajaran dan kemampuan berbahasa Arab peserta didik. Maka pertanyaan penelitian yang diajukan adalah: (1) bagaimana tingkat profesionalisme guru bahasa Arab pada Madrasah Aliyah Negeri di Lampung Tahun 2016? (2) bagaimana tingkat proses pembelajaran bahasa Arab pada Madrasah Aliyah Negeri di Lampung Tahun 2016? (3) bagaimana tingkat kemampuan Berbahasa Arab bahasa Arab pada Madrasah Aliyah Negeri di Lampung Tahun 2016? (4) adakah hubungan proses pembelajaran 
dengan kemampuan Berbahasa Arab bahasa Arab pada Madrasah Aliyah Negeri di Lampung Tahun 2016?. Penelitian ini bertujuan memberikan data valid tentang profesionalisme guru, proses pembelajaran dan kemampuan berbahasa Arab peserta didik di Provinsi Lampung. Jika pertanyaan diatas terjawab, maka hasil ini dapat dijadikan acuan kebijakan peningkatan mutu pendidikan di lingkungan Pemerintahan Provinsi Lampung dan kementerian agama wilayah Lampung.

Untuk menjawab pertanyaan ini maka jenis penelitian yang dipilih adalah penelitian survei dengan mengumpulkan informasi dari sampel melalui angket. Tujuan penelitian survei ini tidak hanya ingin meneliti peta tentang profesionalisme guru, proses pembelajaran bahasa Arab dan keterampilan berbahasa Arab peserta didik, namun juga ingin mengetahui adakah hubungan proses pembelajaran dengan keterampilan berbahasa Arab. sampel penelitian dari unsur guru bahasa Arab sebanyak 49 orang. Sedangkan sampel dari unsur peserta didik adalah sebanyak 382 orang. Penetapan sampel akan disebar secara merata di seluruh MAN Provinsi Lampung.

\section{B. Hasil Penelitian dan Pembahasan}

\section{Profesionalisme Guru Bahasa Arab di MAN Provinsi Lampung}

Data profesionalisme guru bahasa Arab di MAN Provinsi Lampung diambil menggunakan instrumen angket/quesioner yang berisi daftar pernyataan yang diberikan kepada guru bahasa Arab. Hasil uji statistik deskriptif data skor angket profesionalisme guru diketahui bahwa responden yang berada pada level sangat rendah adalah $0 \%$, pada level rendah adalah $24,4 \%$, pada level sedang sebanyak $75.6 \%$, pada level tinggi $0 \%$ dan level sangat tinggi juga $0 \%$.

\section{Proses Pembelajaran Bahasa Arab di MAN Provinsi Lampung}

Data tentang proses pembelajaran bahasa Arab di MAN Provinsi Lampung diambil dengan menggunakan instrumen angket/quesioner yang berisi daftar pernyataan yang diberikan kepada peserta didik. Hasil uji statistik deskriptif data skor angket proses pembelajaran bahasa Arab diketahui bahwa rata-rata nilai proses pembelajaran bahasa Arab sebesar 48,12 yang berada pada rentang sedang. Dari hasil analisis, diketahui bahwa responden yang berada pada level sangat rendah 
adalah $0 \%$, pada level rendah adalah 22,3\%, pada level sedang sebanyak 55,3\%, pada level tinggi $22.4 \%$ dan level sangat tinggi juga $0 \%$.

\section{Kemampuan Bahasa Arab Peserta Didik di MAN Provinsi Lampung}

Kemampuan dalam bahasa Inggris disebut ability. Ability diarti sebagai kemampuan, kecakapan, ketangkasan, bakat, kesanggupan, merupakan tenaga (daya kekuatan) untuk melakukan suatu perbuatan. ${ }^{20}$ kemampuan (ability) adalah kecakapan atau potensi menguasai suatu keahlian yang merupakan bisa merupakan bawaan sejak lahir, bisa juga merupakan hasil latihan atau praktek dan digunakan untuk mengerjakan sesuatu yang diwujudkan melalui tindakannya. Sedangkan kemampuan berbahasa Arab adalah kecakapan peserta didik terhadap empat keterampilan berbahasa Arab seimbang yang terdiri dari keterampilan istima', keterampilan kalam, keterampilan qira'ah dan keterampilan kitabah yang merupakan hasil proses pembelajaran bersama guru dalam kurun waktu tertentu.

Keterampilan menyimak adalah suatu proses yang mencakup kegiatan mendengarkan bunyi bahasa, mengidentifikasi, menginterpretasikan, dan mereaksi atas makna yang terkandung di dalam teks yang didengar untuk memperoleh informasi, menangkap isi, serta memahami makna komunikasi dari apa yang didengar. Sebagai salah satu keterampilan reseptif, keterampilan menyimak menjadi unsur yang harus lebih dahulu di kuasai oleh peserta didik. Keterampilan Berbicara (Maharah Kalam) adalah kemampuan mengucapkan bunyi-bunyi artikulasi atau kata-kata untuk mengekspresikan, menyatakan serta menyampaikan pikiran, gagasan, dan perasaan. ${ }^{21}$ Berbicara dalam bahasa Arab diistilahkan dengan kalam didefinisikan sebagai kemahiran berbicara merupakan bahasa lisan untuk mengekspresikan ide-ide pikiran, dan pada dasarnya bahasa itu adalah kalam. ${ }^{22}$ Dalam bahasa Inggris kalam diartikan speaking yang berarti kegiatan untuk mengungkapkan atau menyampaikan pendapat, perasaan, ide-ide kepada lawan bicara dengan melibatkan aspek psikologis, psiologis (artikulator), dan fisik (akustik)

20 J.P. Chaplin, Kamus Lengkap Psikologi, Terjemahan K. Kartono (Jakarta: PT Raja Grafindo Persada, 2000), h. 251.

${ }^{21}$ Henry Guntur Tarigan, Metodologi Pembelajaran Bahasa I (Bandung: Penerbit Angkasa, 1991), h. 15.

22 Abdurrahman Ibn Ibrahim and Al-dilalah-Fauzan, Idhaat Ta'lim Al-Lughah Al-Arabiyah Li-Ghairi an-Nathiqiina Biha (Riyadh: T.P., 2011), h. 185. 
secara bertahap. ${ }^{23}$ Maka kemampuan kalam adalah kemampuan seseorang dalam mengekspresikan ide-ide, keinginan dalam bentuk wacana lisan dengan menggunakan bahasa Arab .

Keterampilan berbahasa Arab yang ketiga adalah membaca atau qira'ah. Keterampilan membaca adalah keterampilan seseorang menangkap pesan, yang disampaikan penulis dengan perantara kata-kata dalam bentuk bahasa tulis. Apabila pesan tersurat dan tersirat dapat dipahami oleh pembaca, maka pembaca memiliki kemampuan yang baik. ${ }^{24}$ Keterampilan membaca bertujuan (1) kemampuan peserta didik dalam membaca keras dengan melapalkan bunyi Arab dengan benar, (2) kemampuan peserta didik membaca diam dan memahami pokok pokiran materi bacaan (3) kemampuan peserta didik mengembangkan kemampuan mendengar dan memahami apa yang didengar dan dapat mengungkapkannya dengan benar". ${ }^{25}$ Keterampilan membaca mengandung dua aspek keterampilan .Pertama mengubah lambang tulis menjadi bunyi. Kedua, menangkap arti dari seluruh situasi yang dilambangkan dengan lambang-lambang tulis dan bunyi tersebut. Akan tetapi inti keterampilan membaca ini terletak pada aspek kedua. Ini tidak berarti bahwa keterampilan dalam aspek pertama tidak penting, sebab keterampilan dalam aspek yang pertama mendasari keterampilan yang kedua. Betapapun keduanya merupakan tujuan yang hendak dicapai dalam pengajaran bahasa. Secara umum tujuan pengajaran membaca adalah agar peserta didik dapat membaca dan memahami teks $\mathrm{Arab}^{\prime \prime} .{ }^{26}$ Keterampilan menulis adalah disebut juga maharah al-kitabah merupakan kemampuan dalam mendiskripsikan atau mengungkapkan isi pikiran, mulai dari aspek yang sederhana seperti menulis kata-kata sampai kepada aspek yang kompleks yaitu mengarang". ${ }^{27}$

Disamping memahami keterampilan berbahasa di atas dan mampu mengajarkannya, guru juga perlu memahami konsep pemerolehan

23 A. L. Chaney and T. L. Burke, Teaching Oral Communication in Grades K-8 (Boston: Allyn \& Bacon, 1998), h. 13. 2008), h. 63.

${ }^{24}$ H.G. Widdowson, Teaching Language as Communication (London: Oxford University Press,

${ }_{25}$ Mohammad Abdul Qadir Ahmad, Turuq Ta'lim Al-Lughah Al-Arabiyaj, 5th ed. (Cairo: Maktabah an-Nahdhah al-Mishriyyah, 1986), h. 120-121.

26 Ahmad Fuad Effendy, Metodologi Pengajaran Bahasa Arab (Malang: Misykat, 2005), h. 127.

27 Acep Hermawan, Metodologi Pembelajaran Bahasa Arab, 1st ed. (Bandung: PT. Remaja Rosdakarya, 2011), h. 130. 
bahasa.Pemerolehan bahasa adalah salah satu cara manusia untuk dapat menguasai dan menggunakan suatu bahasa yang dipelajari atau bahasa sasaran yang disesuaikan dengan perkembangannya sebagaimana diungkapkan Krashen: "Language acquisition is very similar to the process children use in acquiring first and second languages. It requires meaningful interaction in the target language-natural communication". ${ }^{28}$ Dalam pandangan Krashen pemerolehan bahasa dapat dilakukan dengan beberapa cara:

"The first way is language acquisition, a process similar, if not identical, to the way children develop ability in their first language. Language acquisition is a subconscious process; language acquirers are not usually aware of the fact that they are acquiring language, but are only aware of the fact that they are using the language for communication. ......The second way to develop competence in a second language is by language learning..29"

Sementara Muhammad Ali al Khauly berpendapat bahwa pemerolehan bahasa kedua tidak sama dengan pemerolehan bahasa pertama atau bahasa ibu. pemerolehan bahasa ada dua cara yang dapat dilakukan. Pertama, bahwa kompetensi bahasa diperoleh secara alami dan tanpa disadari, bisa melalui kondisi alamiah didapat dilingkungan keluarga dan masyarakat. Seseorang berbahasa tanpa mengetahui pengetahuan tentang bahasa itu,tetapi mengetahui mana yang benar dan yang salah. .Kedua, adalah dengan pembelajaran bahasa, yaitu belajar bahasa untuk mengetahui tentang bahasa atau pengetahuan formal terhadap bahasa tersebut, baik dari segi tata bahasanya maupun pengetahuan bahasa itu. ${ }^{30}$ Pemerolehan bahasa dapat dilakukan dengan tiga cara: yaitu : at ta'lim al-dhamny (learning), at-ta'lim ghairu ar rasmy (informal learning), wa ta'lim al thabi'iy (natural learning) ${ }^{31}$ Kompetensi bahasa Arab dapat dikembangkan kepada peserta didik non Arab melalui proses belajar. Dalam proses belajar peserta didik berikan kesempatan seluas-luasnya dengan mengoptimalisasikan segala komponen terkait. Pemerolehan bahasa Arab sebagai

28 Stephen D. Krashen, Second Language Acquisition and Second Language Learning (New York: University of Southern California, 2002), h. 1.

29 Stephen D. Krashen, Principles and Practice in Second Language Acquisition (California: Pergamon Press Inc., 2009), h. 10.

${ }^{30}$ Muhammad Ali al-Khauli, Al Hayah Ma'a Lughaten: Atsunaiyyah Al-Lughawiyyah (Mamlakah al Arabiyah Su'udiyah: Jami' al Huquq Mahfudzah 1 al Muallif, 1988), h. 28.

31 Ali Ahmad Madkur and et. al, Al Marja, Fi Manahij Ta'lim Al-Lughah Al-Arabiyah Li An-Natiqina Bi Lughat Hkhra, 1st ed. (Cairo: Kairom Daar al-Fikr, 2010), h. 330. 
bahasa kedua bagi pelajar asing diarahkan pada pencapaian kompetensi dengan menekankan pada aspek keterampilan berbahasa yang meliputi keterampilan berbahasa lisan dan tulisan, baik reseptif maupun produktif. Bahasa sebagai alat komunikasi manusia akan berjalan efektif jika kedua pihak yang berkomunikasi memiliki pengetahuan tentang bahasa dan keterampilan bahasa. Artinya, seseorang dapat berkomunikasi dengan baik kepada orang lain jika ia memiliki kosa kata yang cukup dan pengetahuan tentang cara menyusun bahasa yang baik. Demikian juga halnya bagi yang diajak bicara. Dengan penguasaan bahasa yang baik maka akan terjadi komunikasi yang dapat dipahami satu sama lainnya.

Dalam pandangan Madkur pembelajaran bahasa Arab sebagai bahasa kedua sebagai bahasa kedua ada beberapa kesamaan dengan pemerolehan bahasa perama pada anak yaitu : al mumaratsah (latihan), al Taqlid ( peniruan), al fahmu ( pemahaman, tartib al maharat al-lughawiyah ( penyusunan kemahiran berbahasa), ta'aluma an- nahwu( pembelajaran kaidah) ${ }^{32}$ Dalam pembelajaran bahasa Arab pertama yang harus dilakukan adalah latihan-latihan. Latihan ini bisa berupa mengulang-ulang apa yang didengar berkali-kali. Pengulangan ini akan memberi kepahaman kata dari apa yang didengar tersebut. Latihan-latihan ini hendaknya dilakukan dengan terstruktur sehingga memberikan kemudahan dalam memahami bahasa yang dipelajari. Oleh karena latihan ini merupakan dasar utama dalam pemerolehan bahasa. Proses kedua adalah peniruan. Dalam pemerolehan bahasa anak mencoba melapalkan kata atau kalimat dengan menirukan apa yang didengarnya dari lingkungan belajarnya. Dalam proses ini sering terjadi kesalahan-kesalahan, mulai kesalahan makna dan kesalahan struktur kalimat. Proses ketiga adalah pemahaman. Pada tahap ini pembelajar bahasa mulai memahami apa yang didengarnya dari lingkungan belajarnya. Anak mulai memahami kata atau kalimat dan mulai bisa memberi respon dari apa yang didengarnya melalui ungkapan-ungkapan pendek walaupun masih terjadi kesalahan. Proses keempat adalah penguasaan keterampilan berbahasa. Pada tahap ini pembelajar mulai menguasai keterampilan mendengar, berbicara, membawa dan menulis. Dari prose mendengar, menirukan dan memahami secara berulang-ulang dapat mengantarkan pembelajar bahasa pada 
keterampilan berbahasa yang dipelajari. Dan proses akhir dari pembelajaran adalah penguasaan kaidah. Kaidah-kaidah diberikan ketika pembelajar sudah menguasai istima' dan kalam. Pada pembelajaran qira'ah kaidah kemudian dikenalkan.

Untuk mendapatkan data kemampuan berbahasa Arab pada peserta didik di MA Provinsi Lampung, teknik yang digunakan tes. Tes dilakukan pada responden yang ditunjuk sebagai sampel penelitian. Materi tes meliputi kemampuan istima', kemampuan kalam, kemampuan qira'ah dan kemampuan kitabah. Hasil analisis tes kemampuan berbahasa dijelaskan dibawah ini.

\section{a) Kemampuan Istima'}

Hasil uji statistik deskriptif skor nilai istima' diketahui bahwa rata-rata nilai kemampuan istima' sebesar 37.17 yang berada pada rentang rendah. Dari hasil analisis diketahui bahwa peserta didik yang memiliki kemampuan istima' pada level sangat rendah terdapat $31,6 \%$, pada level rendah $40,8 \%$, pada level sedang $16,9 \%$, pada level tinggi $10,7 \%$ dan pada level sangat tinggi nol persen.

\section{b) Kemampuan Kalam}

Hasil uji statistik deskriptif skor nilai Kalam diketahui bahwa rata-rata nilai kemampuan kalam sebesar 63,9 yang berada pada rentang rendah. Dari hasil analisis diketahui bahwa peserta didik yang memiliki kemampuan kalam pada level sangat rendah terdapat 9,6\%, pada level rendah $79.9 \%$, pada level sedang 7.6 $\%$, pada level tinggi 2,9\% dan pada level sangat tinggi nol persen.

\section{c) Kemampuan Qira'ah}

Hasil uji statistik deskriptif skor nilai Qira'ah diketahui bahwa rata-rata nilai kemampuan qira'ah sebesar 110,48 yang berada pada rentang sedang. Dari hasil analisis diketahui bahwa peserta didik yang memiliki kemampuan qira'ah pada level sangat rendah terdapat $0 \%$, pada level rendah $1 \%$, pada level sedang $42.6 \%$, pada level tinggi $54.9 \%$ dan pada level sangat tinggi 1.5\%.

\section{d) Kemampuan Kitabah}

Hasil uji statistik deskriptif skor nilai kitabah diketahui bahwa rata-rata nilai kemampuan kitabah sebesar 34,0079 yang berada pada rentang sedang. Dari hasil analisis diketahui bahwa peserta didik yang memiliki kemampuan kitabah pada level 
sangat rendah terdapat $0 \%$, pada level rendah $55,9 \%$, pada level sedang $36.1 \%$, pada level tinggi $1 \%$ dan pada level sangat tinggi $7 \%$.

Dari hasil analisis masing-masing keterampilan berbahasa diatas, diketahui bahwa kemampuan bahasa Arab peserta didik MAN Provinsi Lampung adalah kemampuan istima' rendah, kalam rendah, qira'ah sedang dam kitabah sedang.

\section{Pengujian Hipotesis Asosiatif}

Pengujian hipotesis asosiatif adalah pengujian $\mathrm{Ha}$ : ada hubungan proses pembelajaran dengan kemampuan berbahasa Arab pada Madrasah Aliyah Negeri di Lampung Tahun 2016. Dan H0: tidak ada hubungan proses pembelajaran dengan kemampuan berbahasa Arab pada Madrasah Aliyah Negeri di Lampung Tahun 2016 Pengujian hipotesis ini menggunakan analisis regresi linier sederhana. Regresi Linear Sederhana adalah Metode Statistik yang berfungsi untuk menguji sejauh mana hubungan sebab akibat antara proses pembelajaran terhadap kemampuan berbahasa Arab perserta didik. Metode analisis ini digunakan untuk melakukan prediksi tentang karakteristik kualitas maupun Kuantitas. Analisis regresi sebagai berikut:

\section{Hasil Output SPSS}

\section{Coefficients ${ }^{\mathrm{a}}$}

\begin{tabular}{|c|c|c|c|c|c|c|c|c|c|c|}
\hline \multirow[t]{2}{*}{ Model } & \multicolumn{2}{|c|}{$\begin{array}{l}\text { Unstandardize } \\
\text { d Coefficients }\end{array}$} & \multirow{2}{*}{$\begin{array}{l}\text { Standardize } \\
\text { d } \\
\text { Coefficients } \\
\text { Beta } \\
\end{array}$} & \multirow[b]{2}{*}{$\mathrm{t}$} & \multirow[b]{2}{*}{ Sig. } & \multicolumn{3}{|c|}{ Correlations } & \multicolumn{2}{|c|}{$\begin{array}{l}\text { Collinearity } \\
\text { Statistics }\end{array}$} \\
\hline & B & $\begin{array}{l}\text { Std. } \\
\text { Error }\end{array}$ & & & & $\begin{array}{l}\text { Zero- } \\
\text { order }\end{array}$ & Partial & Part & $\begin{array}{l}\text { Toler } \\
\text { ance }\end{array}$ & VIF \\
\hline $\begin{array}{ll}1 & \text { (Constant } \\
& (1 \\
& \text { Proses }\end{array}$ & $\begin{array}{l}-33,575 \\
62,2\end{array}$ & $\begin{array}{l}1,076 \\
, 002\end{array}$ & 145 & $\begin{array}{l}31,205 \\
12,853\end{array}$ & 000 &,- 145 & -145 &,- 145 & 1,000 & 1,000 \\
\hline
\end{tabular}

a. Dependent Variable: BA

Persamaan Regresinya adalah: $\mathbf{Y}^{\prime}=\mathbf{b}_{\mathbf{0}}+\mathbf{b} \mathbf{1} \mathbf{X}$

$\mathbf{Y}^{\prime}$ adalah variabel kemampuan berbahasa Arab yang diramalkan, $\mathbf{b}_{\mathbf{o}}$ adalah konstanta, b1 adalah koefisien regresi dan $\mathbf{X}$ adalah variabel proses pembelajaran. Nilai-nilai koefisien dapat dilihat pada tabel Coefficientsa diatas dan dimasukkan pada persamaan sebagai berikut:

$$
Y^{\prime}=-33,575+62,2 X
$$


- Konstanta $\mathbf{b}_{\mathbf{0}}=-33,575$ Artinya jika proses pembelajaran bahasa Arab nilai adalah nol, maka kemampuan bahasa Arab juga nilainya negatif sebesar 33,575

- Koefisien b1 = 62,2 Artinya jika proses pembelajaran bahasa Arab ditingkatkan mutunya 1 tingkat, maka kemampuan berbahasa Arab akan meningkat sebesar 62,2

Kemudian dilakukan uji $\mathrm{t}$ untuk mengetahui pengaruh variabel proses pembelajaran terhadap kemampuan berbahasa Arab peserta didik, apakah signifikan atau tidak.Tahap pengujian sebagai berikut:

1. Menentukan hipotesis nol dan hipotesis alternatif.

$\mathbf{H}_{\mathbf{0}}: \mathbf{b} \mathbf{1}=\mathbf{0}$ Artinya proses pembelajaran tidak berpengaruh terhadap kemampuan berbahasa Arab peserta didik.

Ha : b1 $\neq \mathbf{0}$ Artinya proses pembelajaran berpengaruh terhadap kemampuan berbahasa Arab peserta didik

2. Menentukan taraf signifikansi. Taraf signifikansi menggunakan 0,05

3. Menentukan $\mathrm{t}$ hitung dan $\mathrm{t}$ kritis

- thitung adalah 12,853 ( dilihat pada tabel Coefficientsa ${ }^{a}$ )

- $\quad \mathrm{t}$ kritis adalah 1,645

4. Pengambilan keputusan

Thitung $\leq \mathrm{t}$ kritis maka $\mathrm{H} 0$ diterima

$\mathrm{T}$ hitung $\geq \mathrm{t}$ kritis maka $\mathrm{HO}$ ditolak

5. Kesimpulan

Dapat diketahui bahwa $\mathrm{t}$ hitung 12,853 > t kritis 1,645, maka hipotesis nol ditolak, kesimpulannya adalah proses pembelajaran berpengaruh terhadap keterampilan berbahasa Arab peserta didik.

Selanjutnya dilakukan analisis koefisien determinasi

Hasil output SPSS sebagai berikut: 
Model Summaryb

\begin{tabular}{|c|c|c|c|c|c|c|c|c|c|c|}
\hline \multirow[t]{2}{*}{ Model } & \multirow[b]{2}{*}{$\mathrm{R}$} & \multirow[b]{2}{*}{$\begin{array}{l}\mathrm{R} \\
\text { Square }\end{array}$} & \multirow[b]{2}{*}{$\begin{array}{l}\text { Adjuste } \\
\text { d R } \\
\text { Square }\end{array}$} & \multirow{2}{*}{$\begin{array}{l}\text { Std. } \\
\text { Error of } \\
\text { the } \\
\text { Estimat } \\
\text { e }\end{array}$} & \multicolumn{5}{|c|}{ Change Statistics } & \multirow{2}{*}{$\begin{array}{l}\text { Durbi } \\
\text { n- } \\
\text { Wats } \\
\text { on }\end{array}$} \\
\hline & & & & & $\begin{array}{l}\mathrm{R} \\
\text { Square } \\
\text { Change }\end{array}$ & $\begin{array}{l}\mathrm{F} \\
\text { Change }\end{array}$ & df1 & $\mathrm{df} 2$ & $\begin{array}{l}\text { Sig. F } \\
\text { Chang } \\
\text { e }\end{array}$ & \\
\hline 1 & $\begin{array}{l}93 \\
1^{\mathrm{a}}\end{array}$ & ,781 & ,798 & 5,44863 & ,021 & 8,142 & 1 & 380 & ,005 & 1,530 \\
\hline
\end{tabular}

a. Predictors: (Constant), Proses Pembelajaran

b. Dependent Variable: Kemampuan Berbahasa Arab

Analisis determinasi $\left(\mathrm{R}^{2}\right)$ digunakan untuk mengetahui seberapa besar prosentase sumbangan pengaruh variabel proses pembelajaran terhadap variabel kemampuan berbahasa Arab. Dari tabel Model Summaryb diatas dapat diketahui bahwa nilai $R^{2}$ sebesar 0,781. Angka $R^{2}$ ini menunjukkan bahwa sumbangan pengaruh variabel proses pembelajaran sebesar 78,1\% terhadap kemampuan berbahasa Arab peserta didik, sedangkan sisanya 21.9\% dipengaruhi oleh faktor lain yang tidak diteliti.

Kemudian dilakukan uji normalitas untuk melihat apakah model regresi memenuhi uji normalitas atau tidak. Hasil Output SPSS sebagai berikut:

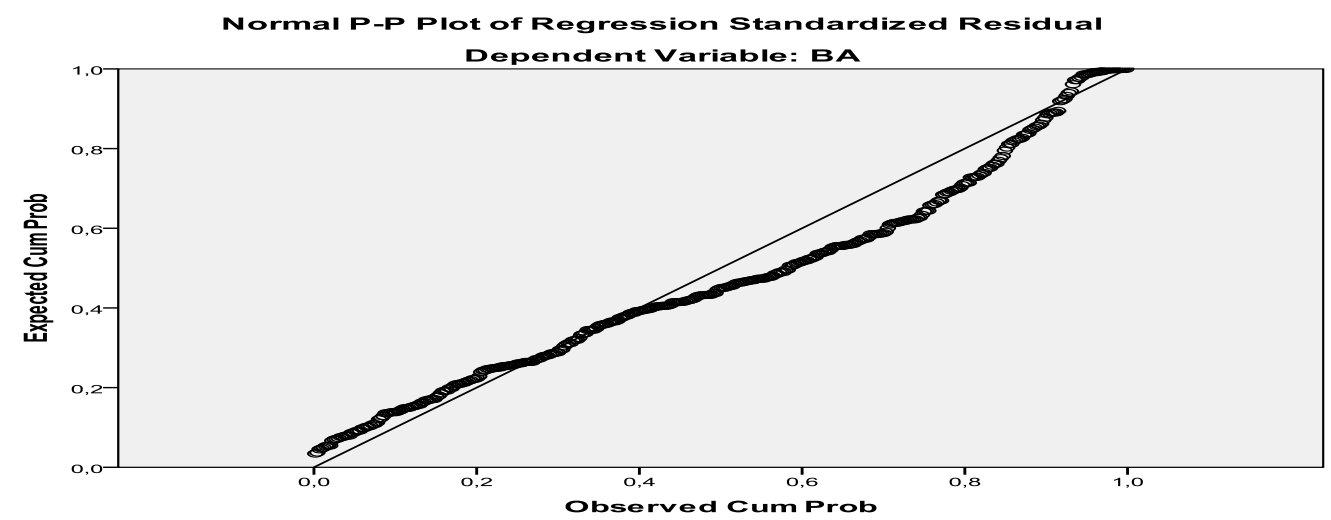

Kriteria pengambilan keputusan yaitu jika data menyebar di sekitar garis diagonal dan mengikuti arah diagonal, maka model regresi memenuhi asumsi normalitas. Jika data menyebar jauh dari garis diagonal maka model regresi tidak memenuhi asumsi normalitas. Dari gambar diatas dapat dilihat bahwa data menyebar di sekitar garis diagonal dan mengikuti arah garis diagonal, maka data terdistribusi dengan normal dan model regresi telah memenuhi asumsi normalitas. 
Dari deskripsi data penelitian diatas diketahui bahwa profesionalisme guru bahasa Arab secara umum yang berada pada level sedang, proses pembelajaran bahasa Arab secara umum berada pada level sedang dan kemampuan bahasa Arab peserta didik secara umum berada pada level rendah. Dari hasil analisis asosiatif diketahui bahwa proses pembelajaran berpengaruh signifikan terhadap kemampuan berbahasa Arab peserta didik dengan konstribusi 78,1\%. Dari hasil analisis ini dapat dinyatakan jika proses pembelajaran bahasa Arab dilakukan maksimal oleh guru, maka pasti kemampuan berbahasa Arab juga akan menjadi baik. Oleh karenanya dapat dimaklumi jika faktanya kemampuan berbahasa Arab peserta didik rendah adalah dampak dari proses dan lingkungan pembelajaran yang dilakukan guru yang belum maksimal.

Tidak maksimalnya peran guru bahasa Arab dalam proses pembelajaran juga dipengaruhi oleh berbagai aspek seperti latar belakang pendidikan guru, kemampuan penggunaan media dan strategi pembelajaran, orientasi mengajar, keikutsertaan guru dalam kegiatan ilmiah bahasa Arab, beban mengajar serta keberadaan lingkungan belajar bahasa Arab. Hasil wawancara dengan guru bahasa diketahui bahwa guru bahasa Arab MAN Provinsi Lampung sebagian besar ( 80,2 \%) berlatar belakang sarjana pendidikan bahasa Arab dan 19.8\% guru berlatar belakang pendidikan sarjana pendidikan agama Islam. Guru yang berlatar belakang pendidikan pondok pesantren hanya 5,8\% dan yang tidak berlatar belakang pondok pesantren 94,2\%. Dari aspek latar belakang pendidikan, guru bahasa Arab sudah cukup baik karena sebagian besar berlatar belakang sarjana pendidikan bahasa Arab, walau yang sempat mengikuti pendidikan di pondok pesantren hanya sedikit.

Pada aspek penggunaan media pembelajaran dalam proses pembelajaran bahasa Arab terdapat 59,2\% guru merasa repot dan mengatakan jika memang diperlukan media untuk meningkatkan keterampilan berbahasa Arab sebaiknya peserta didik langsung dibawa ke laboratorium bahasa. Dan terdapat 30,4 \% guru tidak bisa memanfaatkan dan mengembangkan media pembelajaran keterampilan berbahasa. Dan sebanyak 10,4\% guru menyatakan media pendukung pembelajaran bahasa Arab tidak tersedia di sekolah tempat mengajar. Pada aspek penggunaan variasi metode dan strategi dalam proses pembelajaran bahasa Arab terdapat 73,5\% guru 
menggunakan metode ceramah dan penugasan untuk materi empat keterampilan berbahasa dan 26,5\% guru menggunakan metode qira'ah dan ceramah untuk pengajaran empat keterampilan berbahasa dan unsur bahasa. Fakta ini menunjukkan bahwa guru tidak memiliki kesadaran akan pentingnya media dan strategi pembelajaran dalam proses pencapaian keterampilan berbahasa Arab. Di samping itu, guru juga tidak mampu mengembangkan media dan strategi yang relevan dalam pembelajaran bahasa Arab.

Pada aspek orientasi mengajar bahasa Arab, sebanyak 65,3\% guru menyatakan mengajar bahasa Arab karena tugas pokok dan sertifikat keahlian guru pada bidang bahasa Arab. Dan sebanyak 20.2 \% guru menyatakan bahwa mengajar bahasa Arab merupakan tanggung jawab moral dalam mengembangkan bahasa Arab di Indonesia sebagai bahasa Agama. Dan terdapat 14,5\% guru menyatakan karena di sekolah tempat mengajar tidak ada guru yang bersedia mengajar bahasa Arab.

Dari sisi keikutsertaan guru bahasa Arab pada kegiatan-kegiatan lokakarya, seminar dan workshop terdapat 3.4\% yang pernah mengikuti kegiatan workshop pembelajaran umum dan $0 \%$ dalam kegiatan workshop dan seminar pembelajaran bahasa Arab. Keikutsertaan dalam konferensi pembelajaran bahasa Arab terdapat $0 \%$. Keikutsertaan dalam organisasi pengajar bahasa Arab terdapat $0 \%$.

Pada aspek beban mengajar, guru bahasa Arab sebagian besar $(65,8 \%)$ juga mempunyai tugas mengajar selain bahasa Arab dan (34,2\%) tidak mempunyai tugas mengajar selain bahasa Arab. Tugas mengajar pada mata pelajaran lain selain mata pelajaran bahasa Arab antara lain Fiqih, Alquran-Hadits dan Akidah Akhlak. Tugas mengajar mata pelajaran selain mata pelajaran pokok ini sangat menjadi beban bagi masing-masing guru bahasa Arab sehingga proses mengajar bahasa Arab kurang maksimal.

Dari data diatas diketahui bahwa guru bahasa Arab mengajar hanya karena kewajiban dan bukan panggilan jiwa untuk pengembangan bahasa Arab sebagai bahasa Agama. Guru bahasa Arab juga tidak memanfaatkan media variatif dalam proses pembelajaran karena alasan repot, tidak tahu dan tidak tersedia, sehingga guru tidak pernah mengembangkan media pembelajaran yang sesuai dengan materi yang diajarkan. Data penelitian juga menunjukkan guru tidak menggunakan metode 
dan strategi yang tepat dalam pengajaran empat keterampilan berbahasa (istima', kalam. qira'ah dan kitabah ). Guru hanya menggunakan metode ceramah, membaca dan penugasan untuk semua materi bahasa Arab. Dan sangat sulit mencapai keberhasilan pengajaran jika hanya menggunakan metode ini.

Keterampilan berbicara (maharah kalam) misalnya, sangatlah tidak sesuai jika diajar dengan metode ceramah dan penugasan. Keterampilan berbicara (maharah alkalam) adalah kemampuan peserta didik dalam mengungkapkan bunyi-bunyi artikulasi untuk mengekspresikan ide, pendapat, keinginan, atau perasaan kepada mitra bicara. Tujuan pembelajarannya agar peserta didik dapat melafalkan suarasuara Bahasa Arab dengan intonasi yang beragam dengan cara yang berterima dari pengguna bahasa asli dan mampu mengungkapkan pikiran menggunakan sistem bahasa dan struktur kata yang benar dalam bahasa Arab. Dalam pengajaran keterampilan berbicara ini salah satu hal terpenting adalah suara. Artinya sangatlah urgen mengajarkan pengucapan sejak awal dengan pembelajaran yang benar. Berucap dalam bahasa Arab adalah unsur terbesar yang sulit dirubah atau dibenarkan setelah dipelajari dengan keliru. Maka tugas guru memberi contoh pelapalan atau memperdengarkan bunyi-bunyi bahasa Arab dengan benar. Jika demikian, maka sangat tidak sesuai jika pembelajaran kalam diajarkan dengan metode qira'ah, ceramah dan penugasan. Maka wajar jika kemudian peserta didik tidak menguasai keterampilan ini.

Keterampilan menyimak ( maharah istima') adalah keterampilan yang cukup mendasar dalam aktivitas komunikasi. Oleh karena itu, maka ketrampilan menyimak harus diajarkan dengan metode dan strategi yang sesuai. Ketrampilan menyimak adalah satu bentuk ketrampilan berbahasa yang bersifat reseptif. Implikasi dalam pelaksanaan pengajaranmya adalah guru hendaknya memulai pelajarannya dengan kegiatan lisan yaitu dengan memperdengarkan secara langsung dan tidak dengan membaca tentang ujaran-ujaran bahasa Arab baik berupa kata-kata maupun kalimat. Guru memperdengarkan kata-kata baru, ungkapan-ungkapan baru, atau pola kalimat baru. Kegiatan ini adalah untuk membiasakan peserta didik mendengar ujaran dan mengenal dengan baik tata bunyi bahasa Arab dengan benar. Jika demikian, bagaimana mungkin kegiatan pengajaran istima' diajarkan dengan hanya 
menggunakan metode ceramah dan penugasan. Maka sangatlah sulit bagi peserta didik untuk bisa menguasai keterampilan menyimak.

Hasil observasi lapangan terhadap lingkungan belajar bahasa Arab di MAN Provinsi Lampung didapati data bahwa lingkungan pembelajaran bahasa Arab sangat tidak mendukung. Pertama, lingkungan pandang dan penglihatan seperti papan informasi, pengumuman, liflet dan majalah dinding tidak ada yang bertulis bahasa Arab, semua masih menggunakan bahasa ibu. Kedua, lingkungan pendengaran dan visual tidak terdapat disemua MAN provinsi Lampung. Jenis lingkungan ini memungkinkan warga madrasah dapat mendengarkan pengumuman, ceramah, proses pembelajaran dan pemberitahuan guru dalam bahasa Arab. Tidak ada upaya warga madrasah untuk menciptakan lingkungan pendengaran dan visual ini kecuali semuanya menggunakan bahasa Indonesia bahkan bahasa daerah. Ketiga, lingkungan interaksi pembelajaran. Dalam interaksi pembelajaran guru tidak pernah menggunakan bahasa pengantar dengan bahasa Arab. Bahkan untuk pembelajaran kosa kata, guru lebih cenderung melakukan penerjemahan langsung dari pada menggunakan bahasa sasaran dengan bantuan media. Keempat, lingkungan akademik yang sangat tidak mendukung. Diketahui bahwa sistem mikro madrasah tidak mendukung terciptanya sistem berbahasa dilingkungan sekolah seperti adanya sistem yang mengharuskan semua warga sekolah diwajibkan berbahasa Arab pada hari-hari tertentu. Kelima, lingkungan psikologis di madrasah yang tidak mendukung terhadap pembelajaran bahasa Arab. Artinya tidak ada upaya bagi pengelola madrasah termasuk guru untuk menumbuhkan motivasi berbahasa, minat dan rasa senang terhadap bahasa Arab yang kemudian berdampak pada reaksi negatif pada peserta didik seperti menganggap bahwa belajar bahasa Arab tidak penting, tidak gaul dan pelajaran sulit.

Fakta menunjukkan bahwa guru sangat tidak siap dalam proses pembelajaran. Ketidaksiapan ini dapat dilihat dari penggunaan metode dan strategi dalam proses pembelajaran, disamping penggunaan media yang tidak variatif. Meskipun sebagian besar guru bahasa Arab di MAN Provinsi Lampung adalah sarjana pendidikan bahasa Arab. Dalam proses perjalanan karir sebagai guru bahasa Arab, para guru tidak pernah melakukan recharging keilmuan khususnya pada ranah pembelajaran 
bahasa Arab. Para guru tidak pernah terlibat aktif dalam kegiatan workshop, seminar dan konferensi pembelajaran bahasa Arab. Akibatnya adalah para guru tertinggal informasi pengembangan pembelajaran bahasa Arab yang kemudian berdampak proses pembelajaran bahasa Arab yang dilakukan guru bersifat monoton. Tidak ada interaksi aktif antara guru dan peserta didik ketika proses pembelajaran. Guru tidak menggunakan media pembelajaran yang variatif dalam mengajarkan bahasa Arab baik pada aspek empat keterampilan bahasa maupun unsur bahasa seperti kosa kata dan gramatika. Guru tidak memiliki ide-ide kreatif untuk menghidupkan kelas dan tidak pernah melakukan orkestrasi proses sehingga proses pembelajaran hanya terjadi satu arah. Kondisi ini semua merupakan penyebab rendahnya kemampuan berbahasa Arab peserta didik. Di samping komponen guru, komponen lingkungan berbahasa yang tidak kondusif. Lingkungan belajar sangat tidak mendukung dalam penumbuhan kemampuan berbahasa Arab. Lingkungan berbahasa Arab yang pasif ini disebabkan sistem yang dibangun tidak mengarah pada pengembangan berbahasa warga madrasah. Kondisi-kondisi inilah yang menjadi penyebab utama rendahnya kemampuan berbahasa Arab peserta didik.

\section{Simpulan dan Rekomendasi}

Dari hasil analisa data, disimpulkan bahwa profesionalisme guru bahasa Arab berada pada level sedang, proses pembelajaran bahasa Arab berada pada level sedang dan kemampuan bahasa Arab peserta didik berada pada level rendah. Hasil analisis asosiatif diketahui bahwa proses pembelajaran berpengaruh signifikan terhadap kemampuan berbahasa Arab peserta didik Oleh karenanya dapat dimaklumi jika faktanya kemampuan berbahasa Arab peserta didik rendah adalah dampak dari proses dan lingkungan pembelajaran yang dilakukan guru yang belum maksimal.

Tidak maksimalnya peran guru bahasa Arab dalam proses pembelajaran dipengaruhi oleh aspek kemampuan penggunaan media dan strategi pembelajaran, orientasi mengajar, keikutsertaan guru dalam kegiatan ilmiah bahasa Arab, beban mengajar serta keberadaan lingkungan belajar bahasa Arab. Walau guru bahasa Arab mayoritas sarjana pendidikan bahasa Arab, namun para guru tidak pernah 
terlibat dalam kegiatan-kegiatan ilmiah bahasa Arab seperti workshop, seminar dan konferensi. Dampaknya, para guru tidak update terhadap perkembangan pembelajaran bahasa Arab yang kemudian berakibat tidak berhasilnya guru dalam proses yang kemudian berimbas tidak berhasilnya tujuan pembelajaran yaitu penguasaan empat keterampilan berbahasa seimbang. Ketidakberhasilan pembelajaran bahasa Arab juga disebabkan oleh lingkungan yang tidak partisipatif. Lingkungan berbahasa Arab yang pasif ini disebabkan sistem yang dibangun tidak mengarah pada pengembangan berbahasa warga madrasah.

\section{DAFTAR PUSTAKA}

A. L. Chaney, and T. L. Burke. Teaching Oral Communication in Grades K-8. Boston: Allyn \& Bacon, 1998.

Abdurrahman Ibn Ibrahim, and Al-dilalah-Fauzan. Idhaat Ta'lim Al-Lughah Al-Arabiyah Li-Ghairi an-Nathiqiina Biha. Riyadh: T.P., 2011.

Acep Hermawan. Metodologi Pembelajaran Bahasa Arab. 1st ed. Bandung: PT. Remaja Rosdakarya, 2011.

Ahmad Fuad Effendy. Metodologi Pengajaran Bahasa Arab. Malang: Misykat, 2005.

Ali Ahmad Madkur, and et. al. Al Marja, Fi Manahij Ta'lim Al-Lughah Al-Arabiyah Li An- Natiqina Bi Lughat Hkhra. 1st ed. Cairo: Kairom Daar al-Fikr, 2010.

Chaplin, J.P. Kamus Lengkap Psikologi, Terjemahan K. Kartono. Jakarta: PT Raja Grafindo Persada, 2000.

Cooper, Paul, and Paul McIntyre. Effective Teaching and Learning. Philadelphia: Open University Press, 1996.

Covey, S. R. The 7 Habits of Highly Effective People. Jakarta: Binarupa Aksara, 1997.

Dimyati, Mudjiono. Proses Belajar Mengajar. Jakarta: Bumi Aksara, 2006.

Henry Guntur Tarigan. Metodologi Pembelajaran Bahasa I. Bandung: Penerbit Angkasa, 1991.

Henson, K.T., and B.E. Eller. Educational Psychology for Effective Teaching. Belmont: Wadsworth Publishing Company, 1999.

H.G. Widdowson. Teaching Language as Communication. London: Oxford University Press, 2008. 
Ibrahim, Bafadal. Dasar-Dasar Manajemen Dan Supervisi Taman Kanak-Kanak. Jakarta: PT Bumi Aksara, 2005.

Kunandar. Guru Profesional Implementasi Kurikulum Tingkat Satuan Pendidikan (KTSP) Dan Persiapan Menghadapi Sertifikasi Guru. Jakarta: PT Raja Grafindo Persada, 2007.

Loghran, J. John. Developing Reflective Practice. London: Falmer Press, 2005.

Majid, Abdul. Perencanaan Pembelajaran: Mengembangkan Standar Kompetensi Guru. Bandung: Remaja Rosdakarya, 2011.

Mohammad Abdul Qadir Ahmad. Turuq Ta'lim Al-Lughah Al- Arabiyaj. 5th ed. Cairo: Maktabah an-Nahdhah al-Mishriyyah, 1986.

Muhammad Ali al-Khauli. Al Hayah Ma'a Lughaten: Atsunaiyyah Al-Lughawiyyah. Mamlakah al Arabiyah Su'udiyah: Jami' al Huquq Mahfudzah 1 al Muallif, 1988.

Mulyasa, E. Standar Kompetensi Dan Sertifikasi Guru. Bandung: Rosda Karya, 2008.

Phillips, J.J. Handbook of Training Evaluation and Measurement Methods. Houson: Publishing Company, 1991.

Powell, William, and Ochan Kusuma. How to Teach Now. Virginia: ASDC, 2011.

Stephen D. Krashen. Principles and Practice in Second Language Acquisition. California: Pergamon Press Inc., 2009.

---. Second Language Acquisition and Second Language Learning. New York: University of Southern California, 2002.

Winkel. Psikologi Pengajaran. Jakarta: Grasindo, 1996. 